\title{
PENINGKATAN HASIL BELAJAR DENGAN MENGGUNAKAN MODEL COOPERATIVE LEARNING TYPE INSIDE-OUTSIDE CIRCLE
}

\author{
Yuyun Dwi Haryanti ${ }^{1)}$ \\ yuyundwiharyanti18@gmail.com
}

\begin{abstract}
Penelitian ini dilatarbelakangi rendahnya hasil belajar siswa dalam pembelajaran IPS. Berdasarkan hasil diskusi dengan guru bahwa pembelajaran dilakukan dengan menggunakan model konvensional sehingga siswa tidak berperan aktif dalam proses pembelajaran. Peneliti memberikan solusi model cooperative learning type inside-outside circle (IOC) yang mengoptimalkan hasil belajar siswa sehingga Kriteria Ketuntasan Minimal (KKM) dapat tercapai.Desain penelitian menggunakan classroom action research atau penelitian tindakan kelas. Penelitian dilakukan dalam 3 siklus melalui pengkajian berdaur yang terdiri atas 4 tahap yakni : perencanaan, pelaksanaan, pengamatan dan refleksi. Instrumen yang digunakan adalah lembar observasi untuk aktivitas guru dan siswa serta lembar tes hasil belajar.Subjek penelitian siswa kelas V SD N Karangjambe sebanyak 25 orang. Penelitian berlangsung 3 siklus yang masing-masing siklus dilaksanakan dalam 2 kali pertemuan (2x35 menit), aspek kognitif dengan hasil sebagai berikut: Studi awal siswa tuntas hanya 10 siswa (40\%) dari 25 siswa, pada siklus I siswa yang tuntas belajar 13 siswa (52\%), siklus II siswa yang tuntas 16 siswa (64\%), siklus III siswa yang tuntas 20 siswa (80\%). Pada aspek afektif dan psikomotorik siswa juga meningkat. Kesimpulan yang dapat diambil bahwa model cooperative learning type inside-outside circle (IOC) dapat membantu mempermudah siswa dalam memahami materi serta meningkatkan hasil belajar siswa dalam pembelajaran IPS.
\end{abstract}

Kata Kunci: Hasil Belajar, Pembelajaran IPS, Model Cooperative Learning Type InsideOutside Circle

${ }^{1}$ Penulis adalah dosen tetap Prodi PGSD Fakultas Pendidikan Dasar dan Menengah Universitas Majalengka 


\section{PENDAHULUAN}

Pembelajaran IPS di sekolah dasar sebagai mata pelajaran yang sangat penting diajarkan.Mel alui Pembelajaran IPS siswa dapat mempelajari realitas dan fenomena sosial yang ada di lingkungan siswa maupun masyarakat. Siswa di sekolah dasar penting dibekali tidak hanya teori saja melainkan dapat memahami kehidupan masyarakat dan lingkunganya. Mata pelajaran IPS bertujuan agar peserta didik menjadi warga negara Indonesia yang demokratis, bertanggungjawab serta warga yang cinta damai (Permendikbud, No. 22 Tahun 2006).

Tjokrodikaryo, dalam Hidayati (2008: 1.26), mempelajari IPS pada hakikatnya adalah menelaah interaksi antara individu dan masyarakat dengan lingkungan. Materi IPS digali dari segala aspek kehidupan praktis sehari-hari di masyarakat. Ada 5 macam sumber materi IPS antara lain : (1) segala sesuatu atau apa saja yang ada dan terjadi di sekitar anak; (2) kegiatan manusia; (3) lingkungan geografi dan budaya; (4) kehidupan masa lampau,; dan (5) anak sebagai sumber materi meliputi berbagai segi, dari makanan, pakaian, permainan, keluarga.

$$
\text { Pembelajaran IPS akan }
$$

menyenangkan bagi siswa tentunya dilakukan dengan berbagai strategi pembelajaran. Proses Pembelajaran IPS tidak hanya siswa diam mendengarkan penjelasan dari guru semata melainkan siswa berperan aktif dalam pembelajaran. Siswa dipandang sebagai subjek pembelajaran bukan sebagai objek pembelajaran.

Berdasarkan hasil observasi di SDN Karangjambe dalam pembelajaran IPS guru lebih berperan aktif dimana siswa hanya mendengarkan penjelasan dari guru. Peran serta siswa dalam pembelajaran tidak terlihat karena siswa hanya diam dan tidak memperhatikan apa yang guru sampaikan. Siswa lebih aktif bermain ketimbang dalam proses pembelajaran.
Pembelajaran IPS bagi siswa membosankan karena siswa dituntut guru untuk menghafalkan berbagai materi yang ada pada buku materi IPS. Materi IPS bagi siswa sangat banyak untuk dihafalkan sehingga membuat siswa malas untuk belajar. Selain itu, dalam proses pembelajaran IPS siswa hanya duduk diam tanpa melibatkan keaktifan siswa.

Hasil wawancara terhadap guru kelas V SD N Karangjambe menyebutkan bahwa kurang aktif siswa dalam pembelajaran IPS berakibat menurunnya hasil belajar siswa. Daftar nilai yang guru tunjukkan bahwa hanya 10 siswa atau $40 \%$ siswa yang mencapai nilai KKM (Kriteria Ketuntasan Minimal) yaitu 70 .

Pembelajaran IPS di SDN Karangjambe lebih menonjolkan pada hasil belajar siswa pada aspek kognitif saja sedangkan aspek afektif dan psikomotorik siswa dikesampingkan. Hal ini tidak sesuai dengan tujuan pembelajaran IPS bahwa tujuan pembelajaran IPS agar siswa memiliki sikap bertanggungjawab. Tujuan Pembelajaran dikatakan berhasil apabila hasil belajar siswa tercapai.

Popham (1995) menyebutkan bahwa ranah afektif menentukan keberhasilan belajar seseorang. Seseorang yang memiliki minat pada pelajaran tertentu akan mencapai keberhasilan belajar yang optimal, sebaliknya seseorang yang tidak memiliki minat belajar akan sulit untuk mencapai keberhasilan yang optimal. Seseorang yang tidak memiliki minat belajar tidak akan menghayati apa yang sedang dipelajari. Guru selayaknya dapat membangkitkan minat siswa untuk belajar sehingga siswa dapat mencapai keberhasilan dalam mencapai tujuan pembelajaran. Keberhasilan pembelajaran pada ranah kognitif dan psikomotor dipengaruhi oleh kondisi afektif peserta didik.

Nur dalam Trianto (2009: 29) menyebutkan bahwa perkembangan kognitif sebagian besar ditentukan oleh 
manipulasi dan interaksi aktif anak dengan lingkungan. Pengetahuan datang dari tindakan. Piaget yakin bahwa pengalamanpengalaman fisik dan manipulasi lingkungan penting bagi terjadinya perubahan perkembangan. Sementara itu bahwa interaksi sosial dengan teman sebaya, khususnya berargumentasi dan berdiskusi membantu memperjelas pemikiran yang pada akhirnya memuat pemikiran itu menjadi logis.

Penggunaan model kooperatif strategi inside-outside circle sebagai salah satu strategi yang dirancang untuk peserta didik agar bekerja berkelompok dalam suasana gotong royong untuk saling berbagi informasi serta dapat meningkatkan keterampilan berkomunikasi (Lie, 2008: 65). Pembelajaran kooperatif melalui strategi Inside-Outside Circle siswa akan memiliki variasi dalam pembelajaran sehingga memotivasi siswa untuk belajar secara individu maupun kelompok.

Azhary, Yusuf A,dkk. (2013) menyebutkan bahwa proses penerapan model pembelajaran kooperatif model Inside-Outside Circle dapat meningkatkan hasil belajar siswa. Kegiatan pembelajaran model IOC siswa mendapat pengetahuan secara komprehensif serta menjadikan siswa yang kurang aktif menjadi aktif.Hasil belajar dapat diperoleh siswa melalui kegiatan pembelajaran yang bersifat kognitif serta perubahan perilaku siswa (Purwanto, 2011: 44).

Berdasarkan uraian diatas, dapat disimpulkan bahwa dalam pembelajaran IPS diperlukan model pembelajaran yang tepat serta bervariasi dalam meningkatkan hasil belajar siswa sehingga dapat membekali siswa agar dapat berinteraksi di lingkunganya. Peneliti menggunakan model pembelajaran Cooperative Learning Type Inside-outside Circle untuk mengatasi permasalahan dalam pembelajaran IPS sehingga hasil belajar siswa dapat meningkat.

\section{LANDASAN TEORI}

\section{Pembelajaran IPS SD}

Berdasarkan Peraturan menteri Pendidikan Nasional Nomor 22 tahun 2006 tentang standar isi satuan pendidikan dasar dan menengah menyebutkan bahwa mata pelajaran IPS merupakan salah satu mata pelajaran yang diberikan mulai dari SD/MI/SDLB sampai SMP/MTs/SMPLB. Pada jenjang SD/MI mata pelajaran IPS memuat materi geografi, Sejarah, Sosiologi, dan Ekonomi ( Hidayati, 2008: 3-8). Ilmu Pengetahuan Sosial dirumuskan atas dasar realitas dan fenomena sosial masyarakat yang diwujudkan dalam satu pendekatan interdisipliner dari aspek dan cabang-cabang ilmu sosial tersebut (Trianto, 2010: 171). Berdasarkan uraian diatas dapat disimpulkan bahwa IPS adalah ilmu yang mengkaji realitas dan fenomena sosial dalam masyarakat yang terintegrasi dari berbagai disiplin ilmu-ilmu sosial.

Penekanan pembelajaran IPS tidak hanya membekali peserta didik dengan menghafalkan sejumlah konsep yang dikuasai siswa melainkan menekankan pada bekal dalam memahami dan ikut serta dalam menjalani kehidupan di masyarakat. Menurut Solihatin dan Raharjo (2008: 15) menyebutkan bahwa tujuan pendidikan IPS adalah untuk mendidik dan memberi bekal kemampuan dasar kepada siswa untuk mengembangkan diri sesuai dengan bakat, minat, kemampuan dan lingkungannya serta berbagai bekal bagi siswa untuk melanjutkan pendidikan ke jenjang yang lebih tinggi. Gross dalam Solihatin (2009: 14-15) menyebutkan bahwa tujuan pendidikan IPS adalah untuk mempersiapkan siswa menjadi warga negara yang baik dalam kehidupannya di masyarakat.

Al-lamri (2006: 15) menyatakan bahwa hakikat tujuan mata pelajaran IPS adalah sebagai berikut: pertama, membina pengetahuan siswa tentang pengalaman manusia dalam kehidupan bermasyarakat masa lalu, sekarang, dan di masa yang akan datang; kedua, menolong siswa untuk mengembangkan ketrampilan (skill) untuk mencari dan mengolah/ memproses informasi; ketiga, menolong siswa untuk 
mengembangkan nilai atau sikap (values) demokrasi dalam kehidupan bermasyarakat; keempat, menyediakan kesempatan kepada siswa untuk mengambil atau berperan serta dalam kehidupan sosial.

Mata pelajaran IPS bertujuan agar peserta didik memiliki kemampuan yaitu: a) mengenal konsep-konsep yang berkaitan dengan kehidupan masyarakat dan lingkungannya, b) memiliki kemampuan dasar untuk berfikir logis dan kritis, rasa ingin tahu, inkuiri, memecahkan masalah, dan ketrampilan dalam kehidupan sosial, c) memiliki komitmen dan kesadaran terhadap nilai-nilai sosial dan kemanusiaan, d) memiliki kemampuan berkomunikasi, bekerjasama dan berkompetisi dalam masyarakat yang majemuk di tingkat lokal, nasional, dan global (Al-lamri, 2006:4)

Menurut Tjokrodikaryo, dalam Hidayati (2008: 1.26), mempelajari IPS pada hakikatnya adalah menelaah interaksi antara individu dan masyarakat dengan lingkungan. Materi IPS digali dari segala aspek kehidupan praktis sehari-hari di masyarakat. Ada 5 macam sumber materi IPS antara lain : (1) segala sesuatu atau apa saja yang ada dan terjadi di sekitar anak sejak dari keluarga, sekolah, desa, kecamatan sampai lingkungan yang luas negara dan dunia dengan berbagai permasalahannya; (2) kegiatan manusia misalnya: mata pencaharian, pendidikan, keagamaan, produksi, komunikasi, dan transportasi; (3) lingkungan geografi dan budaya meliputi segala aspek geografi dan antropologi yang terdapat sejak lingkungan anak yang terdekat sampai yang terjauh; (4) kehidupan masa lampau, perkembangan kehidupan manusia, sejarah yang dimulai dari sejarah lingkungan terdekat sampai yang terjauh, tentang tokoh-tokoh dan kejadian-kejadian besar; dan (5) anak sebagai sumber materi meliputi berbagai segi, dari makanan, pakaian, permainan, keluarga.

Berdasarkan uraian diatas dapat disimpulkan bahwa IPS di SD merupakan gabungan dari berbagai mata pelajaran geografi, sejarah, antropologi, dan sosiologi. Tujuan pembelajaran IPS adalah mendidik perilaku siswa yang baik dalam berinteraksi dalam lingkungan masyarakat.

\section{Model Cooperative Learning}

Cooperative Learning atau dikenal dengan istilahPembelajaran kooperatif merupakan sebuah kelompok strategi pengajaran yang melibatkan siswa bekerja secara berkolaborasi untuk mencapai tujuan bersama (Eggen and Kauchak,1996: 279). Pembelajaran kooperatif dapat mengurangi kesenjangan pendidikan khususnya dalam wujud input pada level individual, selain itu juga dapat mengembangkan solidaritas sosial di kalangan siswa (Zahromi dalam Trianto, 2009: 57-58).Model belajar Cooperative Learning merupakansuatu model pembelajaran yang membantu peserta didik dalam mengembangkan pemahaman dan sikapnya sesuai dengan kehidupan nyata di masyarakat, sehingga dengan bekerja secara bersama-sama diantara sesama anggota kelompok akan meningkatkan motivasi, produktivitas, dan perolehan belajar (Solihatin dan Raharjo, 2012: 5). Sintaks model cooperative learning terdiri dari 6 fase yaitu: (1) Menyampaikan tujuan dan memotivasi siswa, (2) Menyajikan informasi, (3) Mengorganisasikan siswa kedalam kelompok kooperatif, (4) Membimbing kelompok, (5) Evaluasi bekerja dan belajar, dan (6)Memberikan Penghargaan.

Berdasarkan pendapat diatas dapat disimpulkan bahwa model Cooperative Learning adalah model pembelajaran yang melibatkan siswa berkolaborasi dalam kelompok untuk mencapai tujuan bersama sehingga dapat meningkatkan motivasi, produktivitas, solidaritas dan perolehan belajar siswa.

\section{Inside-Outside Circle}

Strategi Inside-Outside Circle (IOC) atau lingkaran dalam dan lingkaran luar dikembangkan pertama kali oleh Spencer Kagan dalam Huda (2013: 246- 
247). Penggunaan model kooperatif strategi inside-outside circle pada hakekatnya merupakan salah satu strategi yang dirancang untuk peserta didik agar bekerja berkelompok dalam suasana gotong royong untuk saling berbagi informasi serta dapat meningkatkan keterampilan berkomunikasi (Lie, 2008: 65). Pembelajaran kooperatif melalui strategi Inside-Outside Circle siswa akan memiliki variasi dalam pembelajaran sehingga memotivasi siswa untuk belajar secara individu maupun kelompok.

Tujuan pembelajaran strategi inside outside circle adalah memungkinkan siswa untuk saling berbagi informasi pada saat yang bersamaan. Strategi pembelajaran inside outside circle dapat menumbuh kembangkan keaktifan anak untuk belajar yaitu dengan cara saling berbagi informasi, anak berkesempatan untuk mengolah informasi dan meningkatkan keterampilan berkomunikasi (Huda, 2013: 247). Warsono dan Hariyanto (2013: 224) menyebutkan sintaks atau cara kerja pembelajaran kooperatif tipe inside outside circle adalah sebagai berikut:

1) Seluruh siswa dibagi dalam dua kelompok, ada kelompok di dalam lingkaran kecil yang menghadap ke dinding kelas dan kelompok di dalam lingkaran besar yang menghadap ke arah siswa dalam lingkaran kecil. Jadi, lingkaran kecil di dalam dan lingkaran besar berada di luar mengelilinginya.

2) Setiap siswa membawa sebuah kartu dengan pertanyaan di halaman depan kartu dan jawabannya tertulis di halaman belakangnya.

3) Guru mengumumkan lingkaran mana yang memulai misalnya lingkaran dalam. Siswa yang berada di lingkaran dalam menunjukkan pertanyaan di kartunya kepada siswa di lingkaran luar yang tepat dihadapannya. Siswa yang berada di lingkaran luar menjawab, kemudian jawaban yang di belakang kartu ditunjukkan kepadanya. Secara bergantian siswa yang berada di lingkaran luar menunjukkan pertanyaan di kartunya, setelah dijawab oleh siswa di lingkaran dalam, kemudian ganti menunjukkan jawabannya.

4) Guru memberi perintah kepada kelompok untuk berputar. Perintah ini boleh ke kanan atau ke kiri tetapi harus selalu konsisten. Jika ke kanan harus ke kanan terus dan sebagainya, atau jika searah jarum jam juga harus tetap demikian. Contoh perintah guru, “......lingkaran dalam bergerak ke kanan dua langkah, atau lingkaran luar bergerak selangkah searah jarum jam”. dan sebagainya.

5) Hal ini berlanjut sampai seluruh siswa menghadapi sebagian besar pertanyaan dalam kartu atau waktu yang disediakan habis.

Untuk lebih jelasnya model cooperative learning type inside outside circle dapat digambarkan sebagai berikut:

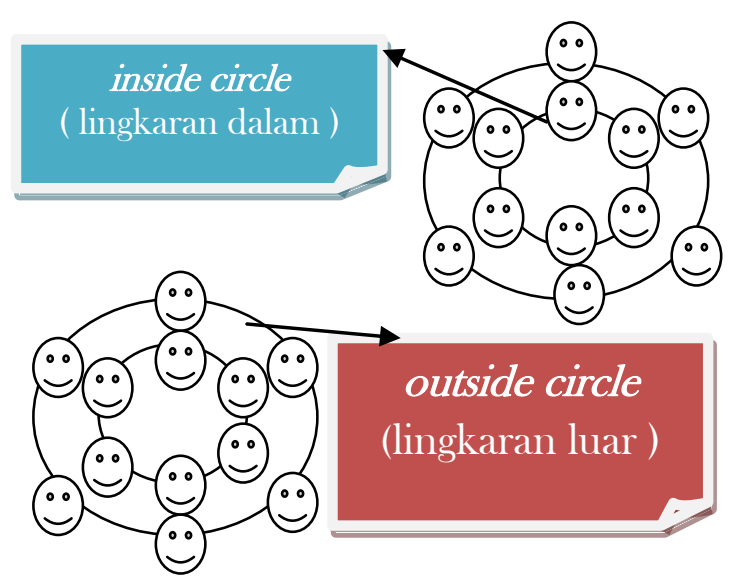

Gambar 1. Model cooperative learning type inside outside circle

\section{Hasil Belajar}

Hasil belajar dapat dijelaskan dengan memahami dua kata yang membentuknya, yaitu "hasil" dan "belajar". Pengertian hasil (product) menunjuk pada suatu perolehan akibat dilakukannya suatu aktifitas atau proses yang mengakibatkan berubahnya input secara fungsional, sedangkan belajar dilakukan untuk mengusahakan adanya perubahan perilaku pada individu yang 
belajar. Perubahan perilaku itu merupakan perolehan yang menjadi hasil belajar, selain hasil belajar kognitif yang diperoleh peserta didik (Purwanto, 2011: 44). Hasil belajar adalah kemampuan yang diperoleh individu setelah melalui kegiatan belajar.Hasil belajar dapat dikatakan berhasil apabila telah mencapai tujuan pendidikan. Di mana tujuan pendidikan berdasarkan hasil belajar peserta didik secara umum dapat diklasifikasikan menjadi tiga yakni: ranah kognitif, ranah afektif, dan ranah psikomotorik (Sudjana,2010).

Ranah kognitif berkenaan dengan hasil belajar intelektual yang terdiri dari enam aspek yakni Pengetahuan, Pemahaman, Penerapan, Aplikasi, Analisis, Sintesis, dan Evaluasi.Kedua aspek pertama disebut kognitif tingkat rendah dan keempat aspek berikutnya termasuk kognitif tingkat tinggi. Ranah afektif berkenaan dengan sikap yang terdiri dari lima aspek yakni penerimaan, jawaban atau reaksi, penilaian, organisasi, dan internalisasi. Ranah psikomotor berkenaan dengan hasil belajar ketrampilan dan kemampuan bertindak.Ada enam aspek psikomotor yakni gerakan refleks, keterampilan gerakan dasar, kemampuan perseptual, keharmonisan atau ketepatan, gerakan ketrampilan kompleks dan gerakan ekspresif dan interpretatif.

\section{METODE PENELITIAN}

Penelitian ini dilakukan di SDN Karangjambe kecamatan Wanadadi kabupaten Banjarnegara pada bulan Mei Tahun Akademik 2014/2015.Subjek penelitian adalah siswa kelas $\mathrm{V}$ dengan jumlah siswa sebanyak 25 orang yang terdiri dari 18 siswa laki-laki dan 17 siswa perempuan. Data penelitian yang dikumpulkan berupa hasil belajar siswa terkait aspek kognitif, afektif dan psikomotor dalam pembelajaran IPS.

Metode penelitian yang digunakan adalah metode kualitatif.Metode kualitatif dengan menggunakan rancangan penelitian tindakan kelas (classroom action
research).Teknik analisis data yang digunakan dalam penelitian ini adalah teknik deskriptif komparatif dan analisis kritis. Teknik deskriptif komparatif digunakan untuk data kuantitatif, yakni dengan membandingkan hasil antar siklus.Peneliti membandingkan hasil sebelum penelitian dengan hasil pada akhir setiap siklus. (Suwandi dan Basrowi, 2008: 70).

Teknik komparatif dalam penelitian ini dilakukan dengan membandingkan hasil penelitian siklus pertama dan kedua, kedua dan ketiga.Hasil komparasi tersebut digunakan untuk mengetahui indikator keberhasilan dan kegagalan dalam setiap siklus.Indikator yang belum tercapai diperbaiki pada siklus berikutnya.Teknik analisis kritis berkaitan dengan data kualitatif, yakni mencakup kegiatan untuk mengungkap kelemahan dan kelebihan kinerja siswa dan guru dalam proses pembelajaran berdasarkan kriteria normatif. Hasil analisis tersebut dijadikan dasar dalam penyusunan perencanaan tindakan untuk tahap berikutnya.

Analisis kritis terhadap hasil belajar siswa dalam pembelajaran IPS mencakup indikator yang telah ditentukan dalam setiap pembelajaran. Analisis data akan dibuat berdasarkan data kualitatif dan data kuantitatif. Data kualitatif dianalisis dalam bentuk paparan naratif.Data kuantitatif dianalisis dalam bentuk deskripsi hasil tes akhir pembelajaran dan rekapitulasi ratarata nilai siklus pertama,kedua dan ketiga.

Rancangan penelitian tindakan kelas terdiri atas rangkaian empat kegiatan yang dilakukan dalam siklus berulang.Empat kegiatan utama yang ada pada setiap siklus yaitu perencanaan tindakan (planing), pelaksanaan tindakan (acting), melakukan pengamatan (observing), dan melakukan refleksi (reflecting). Pada tahap perencanaan disusun rancangan tindakan yang menjelaskan apa, mengapa, kapan, dimana, oleh siapa dan bagaimana tindakan tersebut akan dilakukan. Peneliti menentukan fokus peristiwa yang perlu mendapatkan perhatian khusus untuk 
diamati, kemudian membuat instrumen pengamatan untuk merekam fakta yang terjadi selama tindakan berlangsung.Pada tahap selanjutnya yaitu tindakan, rancangan strategi dan skenario penerapan pembelajaran akan diterapkan. Untuk tahap pengamatan atau observasi sebenarnya berjalan bersamaan dengan saat pelaksanaan tindakan. Pengamatan dilakukan pada waktu tindakan sedang berjalan, jadi keduanya berlangsung dalam waktu yang sama. Kemudian berdasarkan data yang terkumpul dilakukan refleksi terhadap tindakan yang telah dilakukan yang dimaksudkan untuk mengkaji secara menyeluruh tindakan yang telah dilakukan, setelah itu dilakukan evaluasi guna menyempurnakan tindakan berikutnya.Jika terdapat masalah dari proses refleksi maka dilakukan proses pengkajian ulang melalui siklus berikutnya yang meliputi kegiatan : perencanaan ulang, tindakan ulang, pengamatan ulang sehingga permasalahan dapat teratasi (Hopkins dalam Suharjono dan Arikunto, 2005). Adapun daur untuk masing-masing siklus dapat dilihat pada bagan berikut.

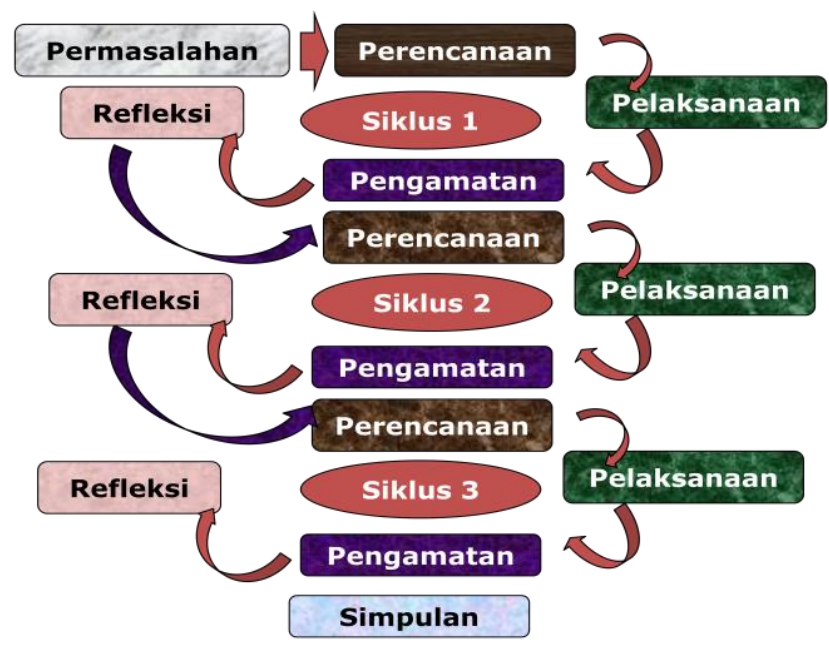

Bagan 1. Siklus Penelitian Tindakan Kelas

Secara lebih rinci prosedur penelitian tindakan untuk setiap siklus dapat diajabarkan sebagai berikut :

a. Perencanaan

Kegiatan yang dilakukan dalam tahap perencanaan ini adalah:

1) Membuat skenario pembelajaran

2) Membuat lembar observasi untuk melihat bagaimana kondisi pembelajaran di kelas ketika model pembelajaran InsideOutside Circle diterapkan .

b. Melakukan Tindakan

Peneliti melaksanakan tindakan sesuai dengan perencanaan. Jenis tindakan yang dilakukan peneliti adalah penggunaan model pembelajaran Inside-Outside Circletujuan untuk meningkatkan hasil belajar siswa. c. Observasi/Pengamatan

Kegiatan observasi dilaksanakan di kelas dengan menggunakan lembar observasi yang telah disusun. Observasi dilakukan untuk mengetahui hasil atau dampak dari tindakan yang dilaksanakan terhadap proses dan hasil pembelajaran pada diri siswa. Hasil observasi tindakan yang telah dilakukan akan dijadikan dasar untuk melakukan refleksi.

d. Refleksi

Hasil yang didapat dalam tahap observasi kemudian dikumpulkan dan dianalisis dalam tahap ini.Dari observasi dapat mereflesikan diri dengan melihat data observasi yang didapat, apakah kegiatan yang telah 
dilakukan dapat meningkatkan hasil belajar siswa.Hasil analisis data dalam tahap ini digunakan sebagai acuan dalam perencanaan siklus selanjutnya.Hasil terhadap tindakan yang dilakukan akan digunakan kembali untuk merevisi rencana pembelajaran jika ternyata tindakan yang dilakukan belum berhasil memecahkan masalah.

\section{HASIL DAN PEMBAHASAN}

Berikut ini adalah hasil penelitian dari penerapan model cooperative learning type inside-outside circle dalam pembelajaran IPS adalah sebagai berikut:

\section{Aspek Kognitif}

Hasil belajar pada aspek kognitif pada setiap siklus mengalami peningkatan. Untuk lebih jelasnya dapat dilihat pada gambar sebagai berikut:

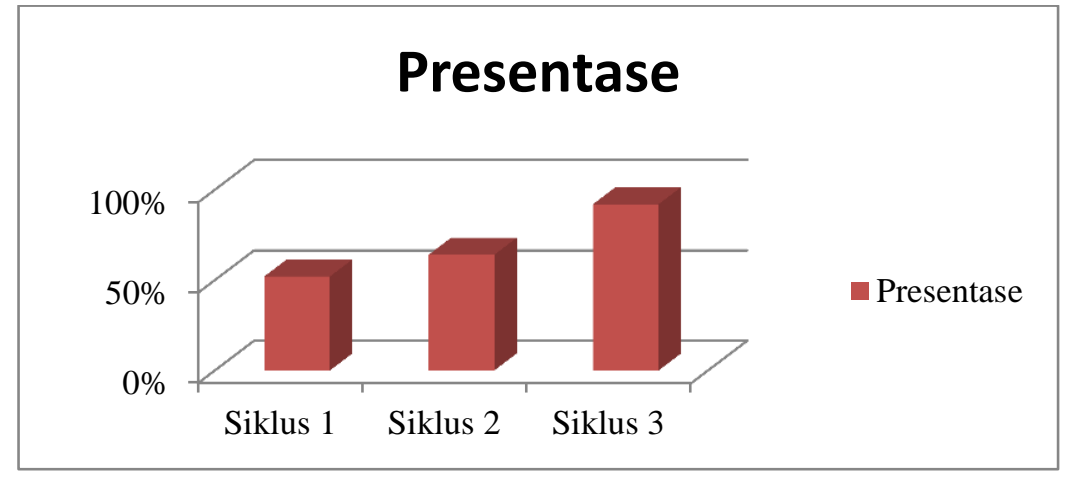

Gambar 2

Persentase hasil belajar siswa pada aspek kognitif

Berdasarkan data grafik diatas, dapat dilihat bahwa pada siklus pertama hanya 13 siswa dari 25 siswa (52\%) siswa yang mencapai KKM. Siklus kedua meningkat menjadi 16 siswa $(64 \%)$ siswa yang mencapai KKM.Siklus ketiga siswa yang mencapai KKM mencapai 23 siswa $(92 \%)$.

\section{Aspek Afektif}

Aspek afektif dilakukan dengan menggunakan lembar observasi.Observasi dilakukan dalam kegiatan diskusi kelompok baik dari segi kerjasama, kedisiplinan dan tanggungjawab siswa. Untuk lebih jelasnya dapat dilihat pada gambar sebagai berikut:

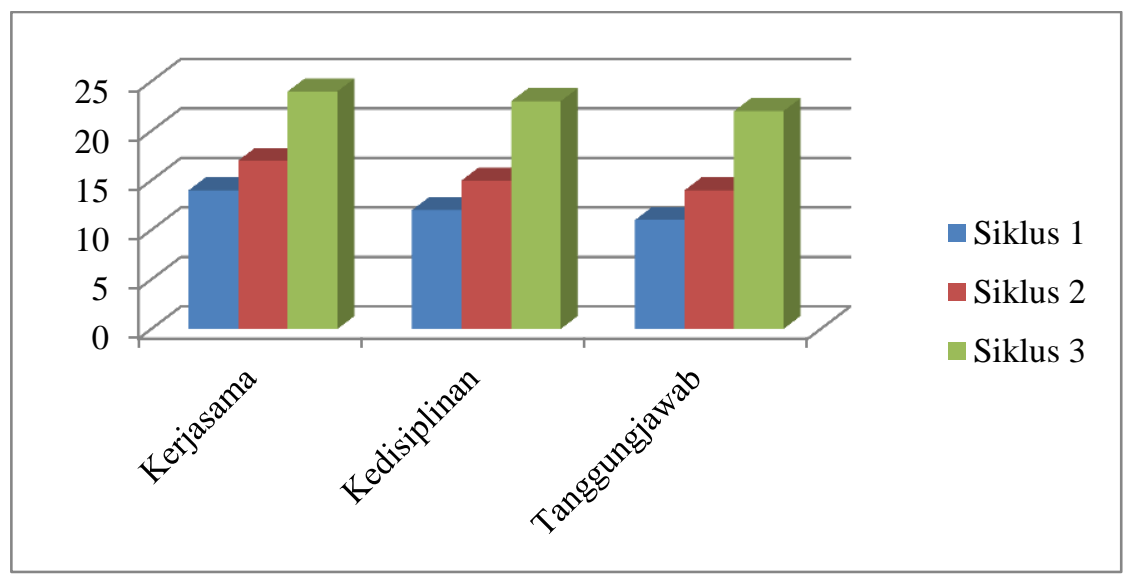

Gambar 3

Persentase hasil belajar siswa pada aspek afektif

Berdasarkan data grafik diatas, dapat dilihat bahwa pada siklus pertama dengan kriteria baik pada aspek kerjasama 14 siswa, aspek kedisiplinan 12 siswa, dan 
aspek tanggungjawab 11 siswa. Pada siklus kedua dengan kriteria baik pada aspek kerjasama 17 siswa, aspek kedisiplinan 15 siswa, dan aspek tanggungjawab 14 siswa. Pada siklus ketiga dengan kriteria baik pada aspek kerjasama 24 siswa, aspek kedisiplinan 23 siswa, dan aspek tanggungjawab 22 siswa.

\section{Aspek Psikomotorik}

Penilaian pada aspek psikomotorik meliputi kesesuaian kartu tanya dengan materi, kesesuaian pertanyaan dengan jawaban, serta kemandirian siswa dalam mengerjakan tugas. Untuk lebih jelasnya dapat dilihat pada gambar sebagai berikut:

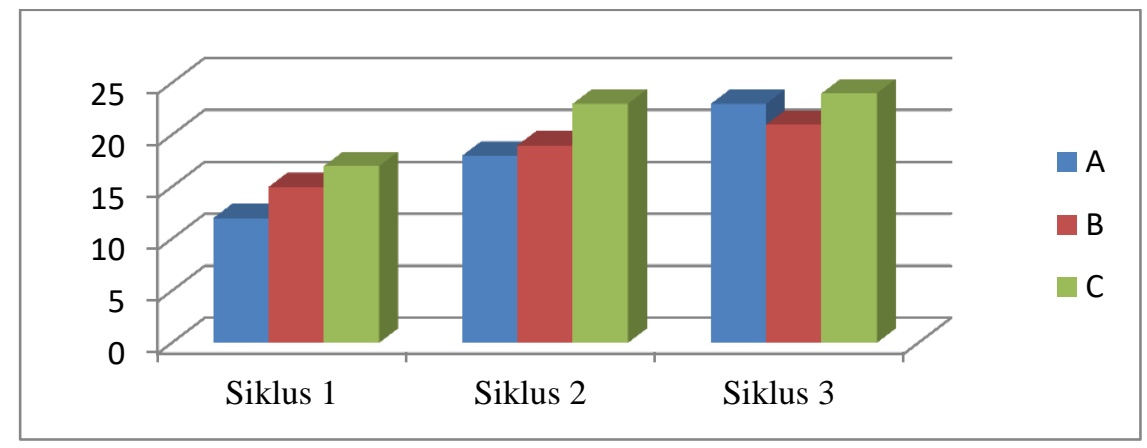

Gambar 4

Hasil belajar pada aspek psikomotor

Berdasarkan data grafik diatas, dapat dilihat bahwa pada siklus pertama aspek, kesesuaian kartu tanya dengan materi hanya 12 siswa, kesesuaian pertanyaan dengan jawaban 15 siswa, dankemandirian siswa dalam mengerjakan tugas 17 siswa. Siklus kedua pada aspek kesesuaian kartu tanya dengan materi hanya 18 siswa, kesesuaian pertanyaan dengan jawaban 19 siswa, dankemandirian siswa dalam mengerjakan tugas 23 siswa. Siklus ketiga pada aspek kesesuaian kartu tanya dengan materi hanya 23 siswa, kesesuaian pertanyaan dengan jawaban 21 siswa, dankemandirian siswa dalam mengerjakan tugas 24 siswa.

\section{SIMPULAN DAN SARAN}

\section{Simpulan}

Penerapan Model Cooperative Learning Type Inside-Outside circle yang dilakukan di SDN Karangjambe pada mata pelajaran IPS dapat meningkatkan hasil belajar siswa baik pada aspek kognitif, aspek afektif maupun psikomotorik siswa. Penerapan model tersebut juga mudah diterapkan dalam proses pembelajaran terutama dalam pembelajaran IPS. Siswa dapat berperan aktif dalam pembelajaran sehingga memudahkan siswa dalam memahami materi yang diajarkan oleh guru.

\section{Saran}

Pada proses pembelajaran menggunakan model inside-ouside circlecocok digunakan pada materi IPS karena menekankan pada penguasaan konsep. Model inside-ouside circlememiliki kelebihan dimana model ini tidak hanya memberikan pengaruh pada aspek kognitif saja melainkan berpengaruh pada aspek afektif dan psikomotor siswa. Namun, dalam implementasi model insideouside circledalam pembelajaran memiliki kelemahan dimana kemampuan siswa dalam ketrampilan menulis kartu tanya mengalami kesulitan sehingga pertanyaan yang ditulis siswa homogen. Hal ini tentunya memerlukan bimbingan guru. Guru sebagai pendidik lebih membimbing siswa dalam menulis informasi pada kartu tanya sehingga pertanyaan yang ditulis siswa lebih bervariatif.

\section{DAFTAR PUSTAKA}


Al-lamri, S.I.H \& Istanti, T. 2006. Pengembangan Pendidikan Nilai dalam Pembelajaran Pengetahuan Sosial di Sekolah Dasar. Bandung: Depdiknas Dirjen Dikti.

Aqib, Zainal. 2006. Penelitian Tindakan Kelas. Bandung: Yama Widya.

Arikunto, S. 2013. Dasar-dasar Evaluasi Pendidikan. Jakarta: Bumi Aksara.

Azhary, A, Yusuf,dkk. (2013).” Penerapan Pembelajaran Kooperatif Model Insideoutside Circle Untuk Meningkatkan Hasil Belajar Apresiasi Dongeng Siswa Kelas VIIC MTSN Juwet Ngronggot Nganjuk". Malang: Universitas Negeri Malang.

BSNP.2006. Standar Isi dan Standar Kompetensi Lulusan untuk Satuan Pendidikan Dasar SD/MI (Peraturan Mendiknas No 22). Jakarta: BP Cipta Jaya.

Eggen, P.D \& Kauchak, P.P. 1996. Strategies for Teachers: Teaching Content and Thinking Skills. Boston: Allyn \& Bacon.

Hidayati, dkk. 2008. Pengembangan Pendidikan IPS SD. Jakarta: Dirjen dikti Depdiknas.

Huda, M. 2013. Model-model Pengajaran dan Pembelajaran. Yogjakarta: Pustaka Pelajar.

Lie, A. 2008. Cooperative Learning. Jakarta: Grasindo.

Popham, William James. 1995. Classroom Assesment: What Teachers need to Know ( $7^{\text {th }}$ Edition). Establised in USA.
Purwanto. 2011. Evaluasi Hasil Belajar. Yogyakarta: Penerbit Pustaka Pelajar.

Sanjaya, W. 2006. Strategi Pembelajaran. Jakarta: Kencana Prenada Media Group.

Solihatin, Etin dan Raharjo. 2012. Cooperative Learning Analisis Model Pembelajaran IPS. Jakarta: Bumi Aksara.

Solihatin, Etin dan Raharjo. 2012. Cooperative Learning Analisis Model Pembelajaran IPS. Jakarta: Bumi Aksara.

Sudjana, N. 2010.Penilaian Hasil Proses Belajar Mengajar.Bandung :PT Remaja Rosdakarya.

Suharjono dan Arikunto S. 2005. Penelitian Tindakan Kelas. Jakarta: Bumi Aksara.

Sumantri, M. dan H.J. Permana. 2001. Strategi Belajar Mengajar. Bandung: CV. Maulana.

Suprayogi, dkk.2011. Pendidikan Ilmu Pengetahuan Sosial. Fakultas Ilmu Sosial Universitas Negeri Semarang: Widya Karya.

Suprijono, A. 2011.Cooperative Learning. Jogyakarta: Pustaka Pelajar.

Susilaningsih, E. dkk.2008. Ilmu Pengetahuan Sosial. Jakarta: Aneka Ilmu.

Suwandi dan Basrowi. 2008. Memahami penelitian Kualitatif. Jakarta: Rineka Cipta.

Trianto. 2009. Mendesain Model 
— 2010. Model Pembelajaran Terpadu. Jakarta: Bumi Aksara.

Pembelajaran Inovatif-Progresif. Surabaya: Kencana Prenada Media Group.

Warsono \& Hariyanto, 2013.Pembelajaran Aktif Teori dan Asesmen. Bandung: PT Remaja Rosdakarya.

Widoyoko Putro, E. 2012. Teknik

Penyusunan Instrumen Penelitian.

Yogjakarta: Pustaka Pelajar. 